\title{
KONSEPSI PENGUKURAN KINERJA ORGANISASI KEMASYARAKATAN (ORMAS) DENGAN BALANCED SCORECARD
}

\author{
Iskandar \\ Sekolah Tinggi Ilmu Islam dan Bahasa Arab (STIBA) Makassar, \\ Jl. Inspeksi PAM Manggala-Antang Makassar \\ E-Mail: iskandarkato28@gmail.com
}

\begin{tabular}{ll}
\hline Keywords : & \multicolumn{1}{c}{ ABSTRACT } \\
\cline { 2 - 3 } $\begin{array}{l}\text { kinerja, ormas, balanced } \\
\text { scorecard }\end{array}$ & Pengukuran kinerja sangat penting bagi organisasi kemasyarakatan \\
& (ormas) untuk mengetabui efektifitas sistem yang berjalan dalam \\
& organisasi tersebut serta untuk mengaturpola kerja bagipengurus dan \\
& karyawannya. Banyak metode yang dapat dipergunakan untuk \\
& mengukur kinerja organisasi, diantaranya Balanced Scorecard dan \\
& cara tradisional. Dalam tulisan ini yang dibahas adalah metode \\
& Balanced Scorecard untuk mengukur kinerja organisasi pada empat \\
& perspektif yaitu perspektif obyek dakwah, perspektif keuangan, \\
& perspektif proses internal dan perspektif karyawan dan kapasitas \\
& organisasi. Balanced Scorecard juga digunakan untuk \\
& menggambarkant kurva kinerja organisasi dengan melakukan \\
& skoring terlebih dabulu.
\end{tabular}




\section{PENDAHULUAN}

Masyarakat sipil didefinisikan sebagai wilayah, arena atau ruang kehidupan sosial di luar keluarga, negara dan pasar di mana individu-individu berorganisasi atau berkelompok untuk memperjuangkan kepentingan bersama. Masyarakat sipil ini mewujud ke dalam berbagai bentuk organisasi dan kelompok seperti: Ormas, lembaga swadaya masyarakat (LSM), kelompok swadaya masyarakat (KSM), Orsos, Organisasi massa, organisasi profesi, organisasi keagamaan, serikat buruh, gerakan sosial, dan lain-lain.

Organisasi merupakan struktur koordinasi terencana yang formal, yang melibatkan dua orang atau lebih, dalam rangka mencapai tujuan yang telah ditetapkan sebelumnya. ${ }^{1}$ Menurut Kast dan James E. Rosenzweig dalam buku yang dikarang oleh Ismail Nawawi yang berjudul "Perilaku Organisasi" menyebutkan bahwa organisasi merupakan sekelompok orang yang terikat secara formal dalam hubungan atasan dan bawahan yang bekerjasama untuk mencapai tujuan bersama pula. Definisi tersebut memberikan informasi bahwa organisasi itu terdiri dari dua bagian penting yaitu sebagai wadah berbagai kegiatan dan sebagai proses interaksi antara orang-orang yang terdapat didalamnya. ${ }^{2}$

Organisasi Masyarakat Sipil (OMS) yang didalamnya termasuk organisasi massa (Ormas) disebut juga sebagai sektor ketiga setelah sektor pemerintah dan organisasi bisnis/sektor swasta. Karena tidak bertujuan ekonomi, maka Ormas disebut juga sebagai organisasi nirlaba atau organisasi yang tidak mencari keuntungan ekonomi. Undang-undang Nomor 16/2001 Pasal 1 Ayat (1) misalnya menyebutkan bahwa Yayasan didirikan untuk mencapai tujuan tertentu dalam bidang sosial, keagamaan dan kemanusiaan.

Salah satu organisasi publik yang diharapkan menjadi partner pemerintah adalah organisasi kemasyarakatan (ormas). Ormas merupakan salah satu wadah untuk menyalurkan pendapat dan pikiran anggota masyarakat warga negara Republik Indonesia dalam meningkatkan keikutsertaannya secara aktif guna mewujudkan masyarakat adil dan makmur.

Organisasi dalam perspektif Islam tidak lain adalah "amanah", yaitu amanah menyebarkan rahmat bagi seluruh alam. Menurut Triyuwono (2009):

Amanah adalah sesuatu yang dipercayakan kepada orang lain untuk digunakan sebagaimana mestinya sesuai dengan keinginan yang mengamanahkan. Ini artinya bahwa pihak yang mendapat amanah tidak memiliki hak penguasaan (pemilikan) mutlak atas apa yang diamanahkan. Ia memiliki kewajiban untuk memelihara amanah tersebut dengan baik dan memanfaatkannya sesuai dengan yang dikehendaki oleh pemberi amanah.

Pemberi amanah, dalam hal ini adalah Allah Sang Pencipta Alam Semesta. Allah menciptakan manusia sebagai wakilnya di bumi (Khalifatullah fil Ardh), sebagaimana difirmankan dalam Q.S.Al-Baqarah/2: $30 .^{3}$

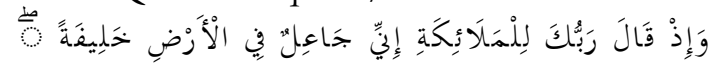

${ }^{1}$ Udai Pareek, Perilaku Organisasi (Jakarta: PT. Pustaka Binaman Pressindo,1996), h. 12.

${ }^{2}$ Ismail Nawawi, Perilaku Organisasi Teori, Transformasi Aplikasi Pada Organisasi Bisnis Publik dan Sosial (Jakarta: Dwiputra Pustaka Jaya, 2010), h. 23.

${ }^{3}$ Departemen Agama RI, Al-Qura'n dan Terjemahannya, (Cet. I; Jakarta: al-Hadi Media Kreasi, 2015), h. 6. 
NUKHBATUL 'ULUM : Jurnal Bidang Kajian Islam

Vol. 3, No. 1 (2017) : Hal. 79-90

Website: https://journal.stiba.ac.id

ISSN : 2685-7537 (online) 2338-5251 (Printed)

Terjemahannya:

Ingatlab ketika Tubanmu berfirman kepada para Malaikat: "Sesunggubnya Aku bendak menjadikan seorang khalifah di muka bumi"

Q.S.Fātir/35: 39.

Terjemahannya:

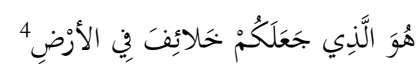

"Dia-lah yang menjadikan kamu khalifah-khalifah di muka bumi"

Allah menghendaki bahwa organisasi yang dikelola manusia harus dilakukan dengan cara-cara yang adil. Untuk mengetahui dengan tepat apa yang dimaksud dengan adil, penerima amanat (manusia) dapat menggunakan potensi internal yang dimilikinya secara baik dan seimbang. Potensi internal yang fitrah tersebut adalah akal dan hati nurani (Triyuwono, 2009).

Konsep amanah menuntut bahwa tugas dan tanggung jawab harus diwakilkan kepada orang-orang yang berkompeten dan dapat dipercaya. Allah berfirman Q.S. Al-Nisā/4:58).

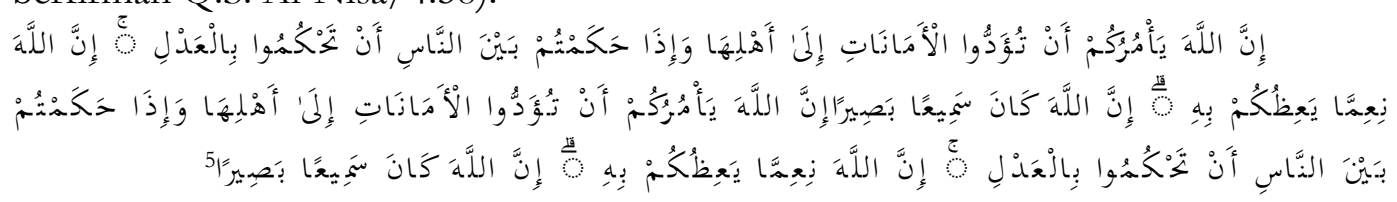

Terjemahannya;

Sesungguhnya Allah menyuruh kamu menyampaikan amanat kepada yang berhak menerimanya, dan (menyuruh kamu) apabila menetapkan hukum di antara manusia supaya kamu menetapkan dengan adil.Sesungguhnya Allah memberi pengajaran yang sebaik-baiknya kepadamu. Sesungguhnya Allah adalah Maha Mendengar lagi Maha Melihat.

Undang-undang Nomor 8 tahun 1985 menjelaskan bahwa yang dimaksud dengan Organisasi Kemasyarakatan adalah organisasi yang dibentuk oleh anggota masyarakat Warganegara Republik Indonesia secara sukarela atas dasar kesamaan kegiatan, profesi, fungsi, agama, dan kepercayaan terhadap Tuhan Yang Maha Esa, untuk berperan serta dalam pembangunan dalam rangka mencapai tujuan nasional dalam wadah Negara Kesatuan Republik Indonesia. ${ }^{6}$ Ormas yang banyak di Indonesia adalah ormas Islam yang bergerak di bidang kesamaan agama. Sebagai mitra pemerintah dan fasilitator masyarakat tentunya dituntut adanya profesionalisme dan kinerja yang maksimal sehingga keberadaannya dapat dirasakan dan diperhitungkan oleh segenap lapisan masyarakat..

\section{PEMBAHASAN}

\section{a. Penilaian Kinerja}

Kinerja merupakan suatu istilah umum yang untuk sebagian atau keseluruhan tindakan atau aktivitas dari suatu organisasi pada suatu periode, seiring dengan referensi pada sejumlah standar seperti biaya-biaya masa lalu atau yang diproyeksikan, suatu dasar efesiensi, pertanggungjawaban atau akuntabilitas manajemen dan

\footnotetext{
${ }^{4}$ Departemen Agama RI, Al-Qura'n dan Terjemahannya, h. 439

5 Departemen Agama RI, Al-Qura'n dan Terjemahannya, h. 87

${ }^{6}$ Kementerian Hukum dan Hak Asasi Manusia Republik Indonesia, Undang-undang Nomor 8 tahun
} 1985. h. 6 
Website: https://journal.stiba.ac.id

ISSN : 2685-7537 (online) 2338-5251 (Printed)

semacamnya (Rivai, 2014). ${ }^{7}$ Penilaian kinerja merupakan suatu tuntutan dalam beraktifitas sebagai sebuah bentuk pengawalan yang mengarah pada tujuan organisasi.

Mulyadi (2001) mendefenisikan penilaian kinerja penentu secara periodik efektifitas operasional suatu organisasi, bagian organisasi, karyawan berdasarkan sasaran, standar, dan kriteria yang telah ditetapkan sebelumnya. Adapun penilaian kinerja yang banyak dipergunakan oleh organisasi maupun perusahaan adalah penilaian dalam perspektif keuangan saja. Artinya bahwa kemajuan organisasi dan keberhasilan karyawan diukur dengan aspek keuangan saja sehingga aspek lainnya terabaikan. ${ }^{8}$

Konsep Islam menegaskan bahwa Allah akan membalas setiap amal atau pekerjaan yang dilakukan oleh seorang hamba sebagaimana firman Allah Q.S AlAhqāf/46: 19.

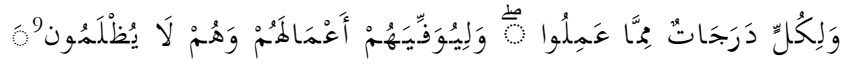

Terjemahannya:

Dan bagi masing-masing mereka derajat menurut apa yang telab mereka kerjakan dan agar Allah mencukupkan bagi mereka (balasan) pekerjaan-pekerjaan mereka sedang mereka tiada dirugikan.

\section{b. Balanced Scorecard}

Balanced Scorecard (BSC) merupakan sistem manajemen strategis yang menerjemahkan visi dan strategi suatu organisasi ke dalam tujuan dan ukuran operasional (Kaplan dan Norton, 1996). Tujuan dan ukuran operasional tersebut kemudian dinyatakan dalam empat perspektif yaitu perspektif finansial, pelanggan (customers), proses bisnis internal (internal business process), serta pembelajaran dan pertumbuhan (learning and growth). ${ }^{10}$

Perspektif finansial menggambarkan keberhasilan finansial yang dicapai oleh organisasi atas aktivitas yang dilakukan dalam 3 perspektif lainnya. Perspektif pelanggan menggambarkan pelanggan dimana organisasi berkompetisi. Perspektif proses bisnis internal mengidentifikasikan proses-proses yang penting untuk melayani pelanggan organisasi. Perspektif pembelajaran dan pertumbuhan menggambarkan kemampuan organisasi untuk menciptakan pertumbuhan jangka panjang.

\section{c. Balanced Scorecard pada Organisasi Publik}

Menurut Kaplan dan Norton (1996), walaupun fockus dan aplikasi awal dari BSC adalah sector swasta, namun bila digunakan dalam organisasi nirlaba bahkan mungkin lebih baik. BSC dengan keempat prespektifnya dapat diterapkan di berbagai organisasi, swasta maupun Negara yang berorientasi pada laba ataupun tidak, karena konsep tersebut sudah mencakup perspektif yang dibutuhkan untuk menilai kinerja organisasi. ${ }^{11}$

Pernyataan visi dan misi suatu organisasi merupakan gambaran ideal organisasi

\footnotetext{
7 Veithzal Rivai, Islamic Human Capital Management Manajemen Sumber Daya Insani. (Jakarta; Penerbit PT. Raja Grafindo, 2014), h. 410

8 Mulyadi, Balanced Scorecard: Alat Manajemen Kontemporer untuk Pelipatganda Kinerja Keuangan Perusahaan, edisi ke-1 (Jakarta; Salemba Empat, 2001), h. 297

${ }^{9}$ Departemen Agama RI, Al-Qura'n dan Terjemahannya, h. 507

${ }^{10}$ Robert S. Kaplan, and David P Norton, The Balanced Scorecard; Translating Startegy Into Action. (Boston; Harvard Scholl Business Press, 1996), h. 10

${ }^{11}$ Robert S. Kaplan, and David P Norton, The Balanced Scorecard; Translating Startegy Into Action, h. 10
} 
Website: https://journal.stiba.ac.id

ISSN : 2685-7537 (online) 2338-5251 (Printed)

atas apa yang dicapai di masa yang akan datang melalui kegiatan operasionalnya. Untuk mencapai visi dan misi tersebut organisasi menyusun rencana-rencana strategis yang harus dilakukan oleh setiap anggota organisasi. Dalam mengimplementasikan rencanarencana strategis tersebut, organisasi sering menghadapi hambatan bahkan kegagalan.

BSC menterjemahkan visi dan strategi organisasi ke dalam seperangkat ukuran yang menyeluruh yang memberi kerangka kerja bagi pengukuran dan sistem manajemen strategis (Kaplan dan Norton, 1996). Jika visi dan strategi dapat dinyatakan dalam bentuk tujuan strategis, ukuran-ukuran dan target yang jelas, yang kemudian dikomunikasikan kepada setiap anggota organisasi, diharapkan setiap anggota organisasi dapat mengerti dan mengimplementasikannya agar visi dan strategi organisasi tercapai.

Organisasi publik adalah organisasi yang didirikan dengan tujuan memberikan pelayanan kepada masyarakat. Hal ini menyebabkan organisasi publik diukur keberhasilannya melalui efektivitas dan efisisensi dalam memberikan pelayanan kepada masyarakat. Untuk itu organisasi publik harus menetapkan indikator-indikator dan target pengukuran kinerja yang berorientasi kepada masyarakat. Pengukuran kinerja pada organisasi publik dapat meningkatkan pertanggungjawaban dan memperbaiki proses pengambilan keputusan (Ittner dan Larcker 1998). ${ }^{12}$

Perbedaan mendasar antara organisasi bisnis dan organisasi publik adalah organisasi bisnis berorientasi profit sedangkan organisasi publik berorienasi nonprofit. Selain itu perbedaan lainnya adalah dari segi tujuan strategis, tujuan financial, stakeholders, dan outcome. Hal ini dapat dilihat pada tabel di bawah ini: ${ }^{13}$

Tabel Perbandingan Organisasi Bisnis dan Publik.

\begin{tabular}{|l|l|l|}
\hline Aspek & Organisasi Bisnis & Organisasi Publik \\
\hline Tujuan Strategi & Persaingan & Mensukseskan misi; \\
\hline Tujuan Finansial & $\begin{array}{l}\text { Profit; pertumbuhan; } \\
\text { Penguasaan pasar }\end{array}$ & $\begin{array}{l}\text { Produktifitas, efisiensi dan } \\
\text { nilai }\end{array}$ \\
\hline Pelaksana & $\begin{array}{l}\text { Stekholder; pembeli; } \\
\text { Manager }\end{array}$ & Pengurus \\
\hline Hasil Akhir & Kepuasan langganan & Customer satisfaction \\
\hline
\end{tabular}

(Sumber: Averson 1999)

Meskipun organisasi publik tidak bertujuan untuk mencari profit, organisasi ini terdiri dari unit-unit yang saling terkait yang mempunyai misi yang sama yaitu melayani masyarakat. Akan tetapi dengan adanya perbedaan-perbedaan antara organisasi bisnis dan publik, maka BSC harus dimodifikasikan terlebih dahulu agar sesuai kebutuhan organisasi publik (Rohm, 2004).

Manfaat BSC dalam organisasi nirlaba menurut Cahyono (2010) adalah:

1. Menjadikan strategi dengan jangka panjang menjadi system manajemen sehari-hari.

2. Menerjemahkan visi dan strategi ke dalam alat ukur yang dapat menentukan komunikasi antar individu dalam organisasi.

3. Memotivasi anggota untuk lebih menentukan performance organisasi.

4. Memudahkan dalam pencapaian tujuan.

${ }^{12}$ Christopher D. Ittner, and David, F. Larcker, "Innovations in Performance Measurement: Trends and Research Implications", (http: \|www.ssrn.com, akses 11 Maret 2018).

${ }_{13}$ Imelda. Implementasi Balanced Scorecard pada Organisasi Publik (Jurnal Akuntasi dan Keuangan, Vol. 6 No. 2, Nopember 2004), h. 107 
Website: https://journal.stiba.ac.id

ISSN : 2685-7537 (online) 2338-5251 (Printed)

Sedangkan menurut Niven (2003), modifikasi BSC dalam empat perspektif itu terdiri dari pelanggan (customer), keuangan (finansial), pembelajaran karyawan dan pertumbuhan (employee learning and growth) dan proses internal (internal process). ${ }^{14}$ 1. Perspektif Pelanggan dan Stakeholder

Pada perspektif ini, organisasi mengidentifikasi pelanggan dan segmen pasar dimana organisasi bersaing. Tujuan yang bisa ditetapkan dalam perspektif ini adalah pemuasan kebutuhan pelanggan. Pemuasan kebutuhan pelanggan dalam Islam dinilai sebagai salah satu dari sekian aspek manfaat seorang muslim kepada muslim yang lainnya. Sehingga seorang harus mengejar hal ini agar menjadi pribadi yang terbaik, sebagimana Rasulullah Shallallahu Alaihi Wasallam bersabda:

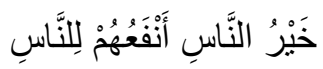
Artinya:

"Sebaik-baik manusia adalah yang paling bermanfaat bagi manusia."

Ukuran-ukuran yang digunakan dalam perspektif ini antara lain retensi pelanggan, kepuasan pelanggan, profitabilitas pelanggan, akuisisi pelanggan baru, market share dan lainnya (Imelda, 2004). ${ }^{15}$

Nilai pelanggan, menurut Kaplan dan Norton (1996) dalam BSC dapat dirumuskan dengan persamaan: ${ }^{16}$

Nilai $=$ Fungsi + Mutu + Citra + Harga + Waktu + Hubungan Dimana:

- Fungsi adalah manfaat generik produk kita bagi pelanggan

- Mutu adalah kesesuaian dengan standar permintaan pelanggan

- Citra adalah daya tarik bagi pelanggan yang tercipta karena proses komunikasi pemasaran

- Harga adalah waktu yang terpakai untuk memenuhi kebutuhan pelanggan serta inovasi untuk mengurangi biaya

- Waktu adalah ketersediaan dan kecepatan proses pemenuhan kebutuhan pelanggan

- Hubungan merupakam dimensi antar manusia dalam proses bisnis dengan pelanggan

2. Perspektif Keuangan

Menurut Imelda (2004), pada perspektif ini organisasi merumuskan tujuan finansial yang ingin dicapai di masa yang akan datang. Tujuan finansial suatu organisasi biasanya menggambarkan apakah implementasi strategi organisasi memberikan kontribusi atau tidak terhadap keberhasilan finansial organisasi. ${ }^{17}$

Al-Qur'an menuntun manusia melakukan pencatatan yang jujur dan berimbang dalam bentuk laporan keuangan. Allah berfirman Q.S. Al-Baqarah/2: 282.

${ }^{14}$ Niven, Paul. R. Adapting The Balanced Scorecard to Fit The Public and Nonprofit Sectors. April 22, 2003, (http: \lwww.qpr.com, akses 2 Maret 2018).

15 Imelda. Implementasi Balanced Scorecard pada Organisasi Publik (Jurnal Akuntasi dan Keuangan, Vol. 6 No. 2, Nopember 2004), h. 107 74

${ }^{16}$ Robert S. Kaplan, and David P Norton, The Balanced Scorecard; Translating Startegy Into Action, h.

17 Imelda. Implementasi Balanced Scorecard pada Organisasi Publik (Jurnal Akuntasi dan Keuangan, Vol. 6 No. 2, Nopember 2004), h. 109 


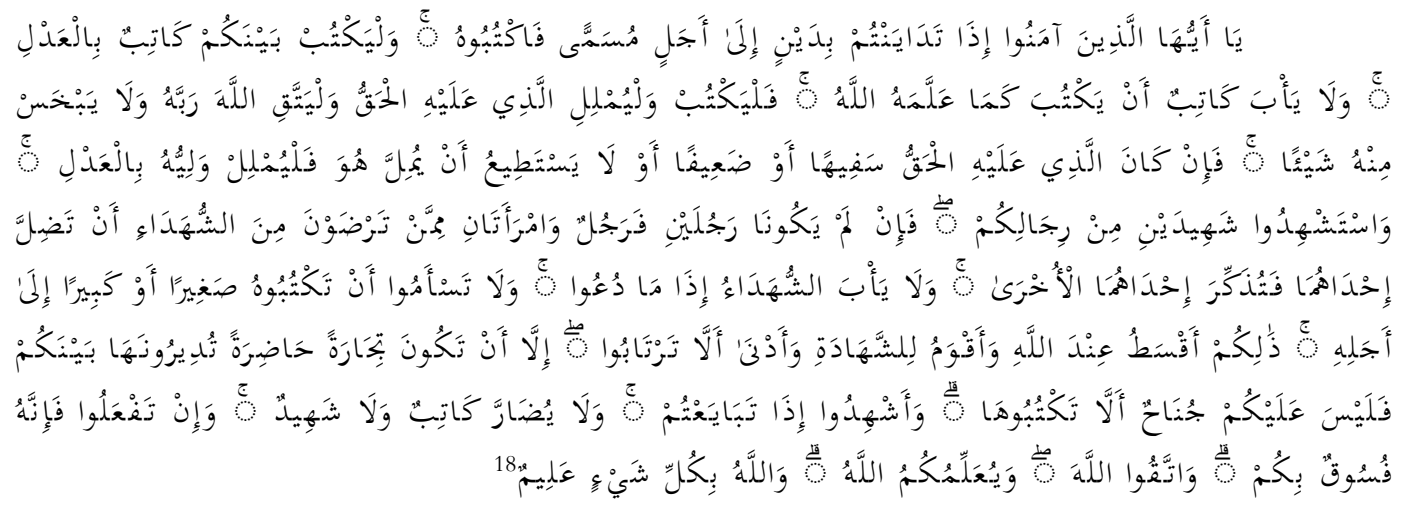

Terjemahannya:

'Hai orang-orang yang beriman, apabila kamu bermu'amalab tidak secara tunai untuk waktu yang ditentukan, hendaklah kamu menuliskannya. Dan hendaklah seorang penulis di antara kamu menuliskannya dengan benar. Dan janganlah penulis enggan menuliskannya sebagaimana Allah mengajarkannya, meka hendaklah ia menulis, dan bendaklah orang yang berbutang itu mengimlakkan (apa yang akan ditulis itu), dan hendaklah ia bertakwa kepada Allah Tubannya, dan janganlab ia mengurangi sedikitpun daripada butangnya. Jika yang berbutang itu orang yang lemah akalnya atau lemah (keadaannya) atau dia sendiri tidak mampu mengimlakkan, maka hendaklah walinya mengimlakkan dengan jujur. Dan persaksikanlah dengan dua orang saksi dari orang-orang lelaki (di antaramu). Jika tak ada dua oang lelaki, maka (boleh) seorang lelaki dan dua orang perempuan dari saksi-saksi yang kamu ridhai, supaya jika seorang lupa maka yang seorang mengingatkannya. Janganlah saksi-saksi itu enggan (memberi keterangan) apabila mereka dipanggil; dan janganlah kamu jemu menulis butang itu, baik kecil maupun besar sampai batas waktu membayarnya. Yang demikian itu, lebih adil di sisi Allah dan lebih menguatkan persaksian dan lebih dekat kepada tidak (menimbulkan) keraguanmu. (Tulislah mu'amalahmu itu), kecuali jika mu'amalah itu perdagangan tunai yang kamu jalankan di antara kamu, maka tidak ada dosa bagi kamu, (jika) kamu tidak. menulisnya. Dan persaksikanlah apabila kamu berjual beli; dan janganlah penulis dan saksi saling sulit menyulitkan. Jika kamu lakukan (yang demikian), maka sesunggubnya bal itu adalah suatu kefasikan pada dirimu. Dan bertakwalah kepada Allab; Allah mengajarmu; dan Allah Maba Mengetahui segala sesuatu."

3. Perspektif Proses Bisnis Internal

Menurut Imelda (2004), bahwa perspektif ini mengidentifikasi proses-proses yang penting bagi organisasi untuk melayani pelanggan. Komponen utama dalam perspektif internal bisnis adalah: 1) proses inovasi yang diukur dengan banyaknya produk baru yang dihasilkan organisasi, waktu penyerahan produk ke pasar, dan lainnya. 2) proses operasional, yang diukur dengan peningkatan kualitas produk, waktu proses produksi yang lebih pendek, dan lainnya. 3) proses pelayanan yang diukur dengan pelayanan purna jual, waktu yang dibutuhkan untuk memberikan pelayanan kepada pelanggan, dan lainnya.

4. Perspektif Karyawan dan Kapasitas Organisasi

18 Departemen Agama RI, Al-Qura'n dan Terjemahannya, h. 49. 
Website: https://journal.stiba.ac.id

ISSN : 2685-7537 (online) 2338-5251 (Printed)

Perspektif ini menggambarkan kemampuan organisasi untuk menciptakan pertumbuhan jangka panjang. Tujuan dalam perspektif ini adalah menyediakan infrastruktur bagi perspektif finansianl, pelanggan dan proses bisnis internal, agar tujuan dari perspektif-perspektif tersebut tercapai. Perspektif ini bertujuan meningkatkan kemampuan karyawan, meningkatkan kapabilitas sistem informasi, dan peningkatan keselarasan dan motivasi. Ukuran yang bisa digunakan antara lain kepuasan karyawan, retensi karyawan, banyaknya saran yang diberikan oleh karyawan, dan lainnya (Imelda, 2004).

Sedangkan Kaplan dan Norton (2000) mengungkapkan tiga kategori utama untuk perspektif pembelajaran dan pertumbuhan, yaitu:

a. Kapabilitas Pekerja

Sebagian besar perusahaan menetapkan tujuan karyawan dari tiga pengukuran utama, yaitu: kepuasan pekerja, retensi pekerja, dan produtivitas pekerja. Umumnya kepuasan pekerja sebagai pendorong retensi dan produktivitas kerja.

b. Kapabilitas Sistem Informasi

Alternatif tolak ukur yang tergolong kelompok ini, ialah: tingkat ketersediaan informasi yang dibutuhkan, tingkat ketepatan informasi yang tersedia, dan jangka waktu untuk memperoleh informasi yang dibutuhkan. Kemampuan sistem informasi memberi dukungan kepada karyawan untuk menyempurnakan proses pelaksanaan yang memerlukan umpan balik yang cepat, tepat waktu, dan teliti mengenai produk/jasa yang diberikan.

c. Motivasi, Pemberdayaan, dan Keselarasan

Tolak ukur yang tergabung dalam kelompok ini yaitu: jumlah saran dari pegawai, jumlah saran yang direalisasikan, jumlah saran yang berhasil guna, dan banyaknya pegawai yang mengerti dan memahami visi dan tujuan perusahaan.

\section{Cara Pengukuran dalam Balanced Scorecard}

Sasaran strategik yang dirumuskan untuk mencapai visi dan tujuan organisasi melalui strategi yang telah dipilih perlu ditetapkan ukuran pencapaiannya. Ada dua ukuran yang perlu ditetapkan untuk mengukur keberhasilan pencapaian sasaran strategik, yaitu ukuran hasil yang merupakan ukuran yang menunjukkan tingkat keberhasilan pencapaian sasaran strategik, dan ukuran pemacu kinerja merupakan ukuran yang menyebabkan hasil yang dicapai. Cara pengukuran dalam BSC adalah mengukur secara seimbang antara perspektif yang satu dengan perspektif yang lainnya dengan tolok ukur masing-masing perspektif. Menurut Mulyadi (2001), kriteria keseimbangan digunakan untuk mengukur sampai sejauh mana sasaran strategik kita capai seimbang di semua perspektif. Skor dalam tabel kriteria keseimbangan adalah skor standar, jika kinerja semua aspek dalam perusahaan adalah "baik".

Skor diberikan berdasarkan rating scale berikut:

\section{Tabel Rating Scale}

\begin{tabular}{|c|c|}
\hline Skor & Nilai \\
\hline-1 & Kurang \\
\hline 0 & Cukup \\
\hline 1 & Baik \\
\hline
\end{tabular}

Sumber: Mulyadi, 2001 


\section{d. Perspektif Keuangan}

Organisasi kemasyarakatan juga merupakan lembaga yang membutuhkan pendanaan dalam opersasional dan pendanaan lainnya. Untuk mengukur kinerja keuangan sebagai organisasi nirlaba atau non profit, maka yang dilihat adalah rasio efektifitas dan rasio efisiensi.

a. Rasio Efektivitas Keuangan

Efektivitas keuangan menggambarkan kemampuan dalam merealisasikan pendapatan keuangan yang direncanakan dibandingkan dengan target yang ditetapkan sesuai dengan potensi internal dan eksternal .

b. Rasio Efisiensi Keuangan

Rasio efisiensi keuangan menggambarkan perbandingan antara besarnya biaya yang dikeluarkan untuk memperoleh pendapatan dengan realisasi pendapatan yang diterima.

\section{e. Mad'u (Obyek Dakwah)}

Metoda yang digunakan dalam perspektif mad'u (obyek dakwah) adalah dengan menggunakan skala likert yang menunjukkan sikap atau tanggapan mad'u (obyek dakwah) terhadap indikator-indikator nilai, yaitu: (a) fungsi, (b) mutu, (c) citra, (d) harga, (e) waktu, dan (f) hubungan.

\section{a. Fungsi}

Fungsi adalah manfaat dakwah bagi mad'u (obyek dakwah). Dakwah yang diberikan diharapkan memberikan nilai manfaat pada obyek dakwah dalam pembinaan kepribadiannya dan tidak hanya sebagai kegiatan rutinitas belaka.

b. Mutu / kualitas

Mutu adalah kesesuaian dengan standar permintaan mad'u (obyek dakwah). Jasa dakwah sebagai produk harus mampu memberikan kepuasan kepada mad'u (obyek dakwah), karena kepuasan mereka merupakan standar kualitas.

c. Citra

Citra adalah daya tarik dakwah bagi mad'u (obyek dakwah). Lembaga dakwah harus menjaga citra di tengah masyarakat apabila hendak mempertahankan obyek dakwah dalam pembinaannya di tengah-tengah persaingan lembagalembaga yang sejenis.

d. Harga

Harga adalah waktu yang terpakai dalam memenuhi kebutuhan obyek dakwah yang berkaitan dengan biaya dan inovasi untuk mengurangi biaya yang ditanggung oleh obyek dakwah.

e. Waktu

Waktu adalah ketersediaan dan kecepatan proses pemenuhan kebutuhan mad'u (obyek dakwah).

f. Hubungan

Hubungan adalah interakasi antar dimensi antara organisasi sebagai pembina di satu pihak dengan obyek dakwah sebagai yang menjadi sasaran pembinaan di pihak lain.

\section{f. Perspektif Proses Internal}

Dalam Perspektif Proses Internal, pimpinan lembaga harus mengidentifikasi proses-proses yang harus diunggulkan untuk mencapai tujuan peningkatan pelayanan dakwah kepada mad'u (obyek dakwah). Perspektif ini memungkinkan pimpinan 
Website: https://journal.stiba.ac.id

ISSN : 2685-7537 (online) 2338-5251 (Printed)

mengetahui seberapa baik pelayanan dakwah mereka berjalan dan apakah dakwah dan layanan mereka sudah sesuai dengan kebutuhan mad'u (obyek dakwah). Metoda yang digunakan dalam Perspektif Proses Internal adalah dengan menggunakan skala likert yang menunjukkan sikap atau pernyataan melalui pengedaran kuesioner kepada setiap departemen yang ada di .

\section{h. Perspektif Karyawan dan Kapasitas Organisasi}

a. Kapabilitas karyawan

Untuk mencapai hasil yang telah direncanakan sangat ditentukan oleh retensi dan produktivitas karyawan. Faktor pendorong untuk menghasilkan produktivitas tinggi adalah tingkat kepuasan kerja yang dirasakan karyawan. Perasaan puas akan membuat para karyawan mencintai pekerjaannya. Kepuasan kerja sangat ditentukan oleh kompetensi staf, infrastruktur teknologi yang memadai serta suasana kerja yang menyenangkan.

b. Kapabilitas Sistem Informasi

menyadari bahwa sistem informasi merupakan alat manajemen yang strategis untuk menyusun ulang prosedur dan proses bisnis, meningkatkan produktivitas, mendukung pelayanan, mengurangi beban dan mendukung dalam pengambilan keputusan.

c. Motivasi, Pemberdayaan, dan Keselarasan

Perspektif ini penting untuk menjamin adanya proses yang berkesinambungan terhadap upaya pemberian motivasi dan inisiatif yang sebesar-besarnya bagi karyawan.

\section{g. Skoring Penilaian Kinerja Berdasarkan Balanced Scorecard}

Setelah mendapatkan data kinerja dari empat perspektif, langkah selanjutnya adalah menilai apakah kinerja lembaga baik atau tidak. Kinerja lembaga diukur dengan skoring dengan pembobotan tiap variabel pada masing-masing perspektif.

Pembobotan ukuran interval yang digunakan untuk mengurutkan variabel berdasarkan suatu atribut. Interval/jarak yang sama pada skala interval dipandang dapat mewakili interval/jarak yang sama pada variabel yang diukur. Jumlah variabel yang diukur adalah 12 yakni efektivitas, efesiensi, fungsi, kualitas, citra, harga, waktu, hubungan, proses-inovasi, kapabilitas karyawan, kapabilitas sistem informasi, serta motivasi dan pemberdayaan, maka total skor "kurang" adalah -12 skor, total skor "cukup" adalah 0 skor, dan total skor "baik" adalah +12 skor.

Tabel IV. 15. Skor Penilaian Balanced Scorecard

\begin{tabular}{|c|c|c|c|}
\hline & Skor & Total Skor & Pengertian \\
\hline Kurang & -1 & -10 & Tingkat prestasi di bawah standar/target \\
\hline Cukup & 0 & 0 & $\begin{array}{c}\text { Tingkat prestasi sesuai dengan } \\
\text { standar/target }\end{array}$ \\
\hline Baik & 1 & 10 & Tingkat prestasi di atas standar target \\
\hline
\end{tabular}

Sumber : Mulyadi, 2001

pada tabel berikut:

Pembobotan hasil dari variabel pada masing-masing perspektif dirangkum 
Tabel Ikhtisar Kinerja Ormas dengan Balanced Scorecard

\begin{tabular}{|c|c|c|}
\hline \multicolumn{1}{|c|}{ Perspektif } & Kriteria & Skor \\
\hline Perpektif Keuangan & & \\
\hline a) Efektifitas & Kurang & 1 \\
\hline b) Efisiensi & Baik & 1 \\
\hline Perspektif Mad'u (Obyek Dakwah) & Baik & 1 \\
\hline a) Fungsi & Baik & 1 \\
\hline b) Kualitas & Baik & 1 \\
\hline c) Citra & Baik & 1 \\
\hline d) Harga & Baik & 1 \\
\hline e) Waktu & Baik & 1 \\
\hline f) Hubungan & & \\
\hline Perspektif Proses Internal & Baik & 1 \\
\hline a) Proses dan Inovasi & Cukup & 1 \\
\hline Perspektif Karyawan dan Kapasitas Organisasi & Cukup & 1 \\
\hline a) Kapabilitas Karyawan & Cukup & 1 \\
\hline b) Kapabilitas Sistem Informasi & & 12 \\
\hline c) Motivasi dan Pemberdayaan & & \\
\hline \multicolumn{2}{|c|}{ Total Skor } & \\
\hline
\end{tabular}

Langkah selanjutnya adalah adalah membuat skala untuk menilai dari total skor tersebut sehingga kinerja lembaga dapat dikatakan "kurang", "cukup" dan "baik". Berikut gambar kurva kinerja :

\section{Gambar. Kurva Kinerja Ormas}

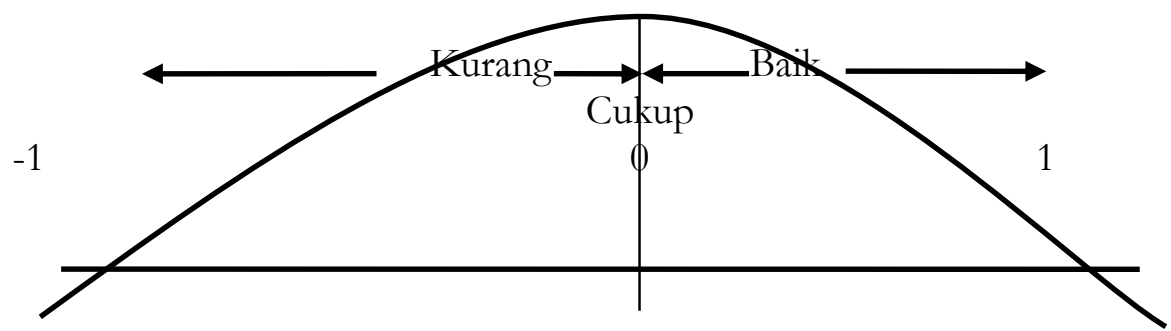

\section{PENUTUP}

Berdasarkan uraian dan analisis yang dikemukakan sebelumnya maka dapat ditarik kesimpulan sebagai berikut:

1. Kinerja keuangan yang terdiri dari rasio efektivitas menunjukkan tingkat keberhasilan pengurus organisasi dalam mencapai target anggaran yang telah direncanakan, sedangkan rasio efisiensi menunjukkan tingkat keberhasilan pengurus organisasi dalam menyelaraskan pembiaayaan mencapai target dengan target yang direncanakan.

2. Kinerja ditinjau dari perspektif obyak dakwah menunjukkan tingkat keberhasilan organisasi dalam memenuhi kebutuhan obyek dakwah dengan menjalankan fungsinya dengan baik serta variabel-variabel lain yang menjadi perekat organisasi dengan oebyek dakwahnya.

3. Kinerja ditinjau dari perspektif proses internal menunjukkan tingkat keberhasilan organisasi dalam melakukan proses dan inovasi dalam 
menjalankan perannya dengan melibatkan seluruh komponen dan bagian dalam organisasi.

4. Kinerja ditinjau dari perspektif karyawan dan kapasitas organisasi menunjukkan tingkat keberhasilan organisasi dalam menyelaraskan antara pemenuhan kepuasan karyawan demi peningkatan produktivitas dengan beban kerja yang diberikan yang diserta dengan peningkatan kapasitas sesuai dengan tuntutan dan kebutuhan.

\section{DAFTAR PUSTAKA}

Al-Qura'n dan Terjemahannya Cet. I; Jakarta: al-Hadi Media Kreasi, 2015.

Cahyono, Roni Tri. Balanced Scorecard Sebagai Alternatif Penilaian Kinerja Klub Sepak. Bola Profesional di Indonesia (Studi Kasus Pada Persijap Jepara). Skripsi tidak diterbitkan. Semarang: Fakultas Ekonomi. Universitas Diponegoro, 2010.

Fauzi. Kamus Akuntansi. Surabaya: Surabaya Indah, 1995.

Imelda. Implementasi Balanced Scorecard pada Organisasi Publik. Jurnal Akuntasi dan Keuangan, Vol. 6 No. 2, Nopember 2004

Indrawijaya, Adam Ibrahim. Teori, Perilaku dan Budaya Organisasi. Bandung.: Refika Aditama, 2010.

Ittner, Christopher D. dan Larcker, David, F. "Innovations in Performance Measurement: Trends and Research Implications", http: \\ww.ssrn.com, akses 11 Maret 2018.

Kaplan, Robert S. and Norton, David P. The Balanced Scorecard; Translating Startegy Into Action. Boston : Harvard Scholl Business Press, 1996.

Mardiasmo. Akuntansi Sektor Publik. Yogyakarta: Penerbit ANDI, 2002.

Mulyadi. Balanced Scorecard: Alat Manajemen Kontemporer untuk Pelipatganda Kinerja Keuangan Perusahaan, edisi ke-1. Salemba Empat. Jakarta, 2001.

Niven, Paul. R. Adapting The Balanced Scorecard to Fit The Public and Nonprofit Sectors. April 22, 2003, (http: \www.qpr.com, akses 2 Maret 2018.

Niven, Paul. R. Balanced Scorecard Step by Step Maximazing Performance and Maintaining Result. John Wiley and Sons Inc. New Yor, 2002.

Rivai, Veithzal. Islamic Human Capital Management. Manajemen Sumber Daya Insani. Jakarta: Penerbit PT. Raja Grafindo, 2014. 